\title{
The Quality of Financial Statements and Performance of Zakat Institutions
}

\author{
Yuningsih Isna ${ }^{1,2, *}$ Fitria Yunita ${ }^{2, *}$ Maratama Willy ${ }^{2}$
}

\author{
${ }^{1}$ Airlangga University, Surabaya, Indonesia \\ ${ }^{2}$ Mulawarman University, Samarinda, Indonesia \\ ${ }^{*}$ Corresponding author. Email: isna.yuningsih@feb.unmul.ac.id
}

\begin{abstract}
The purpose of this study is to test the quality of financial statements and performance of Zakat Institutions by adding contextual factors such as human resources competencies, the application of PSAK 109, IT utilization and Internal control that affect the quality of Financial Statements of Zakat Institutions. The Research object was in East Kalimantan Province. The number of samples used in this study were 57 respondents with the sampling method used was saturated samples. The data analysis method used is multiple regression analysis. The results of this study indicated that Human Resources competencies had a positive and significant effect on the quality of Zakat Institutions' financial reports. However, Implementation of PSAK No. 109 had a positive and insignificant effect on the quality of Zakat Institution's financial statements. Moreover, IT utilization had a positive and insignificant effect on the quality of Zakat Institutions' financial reports. There is a positive and insignificant effect between Internal Control on performance through the quality of Zakat Institutions' financial statements. The research issues raised are the increasing public demand for the Zakat Institutions for the services and accountability while on the other hand the Zakat Institution faced with the report and financial quality are below the expectation. Therefore, Zakat Institutions need to increase their capacity in PSAK 109 and to maximize the use of IT, especially in terms of financial management. Indeed, the Zakat Institution needs to regularly monitor financial records on a regular basis, so as to provide assurance and confidence that the financial records are presented in an honest and true manner.
\end{abstract}

Keywords: Human Resources, PSAK 109, Information Technology, Internal Control, Quality of Financial Statements Introduction.

\section{INTRODUCTION}

The potential for zakat in East Kalimantan Province is quite large, namely IDR 1.2 trillion, while what can be collected is only IDR 100 billion [5]. This indicates that there is a considerable gap between the potential for zakat and its collection realization. This gap is caused by several factors, one of which is the low quality of the financial reports presented by Zakat Institution. Financial reports as a link between the Zakah institution and the muzaki have a vital role in fostering the interest and loyalty of the muzaki in carrying out Zakat, Infaq, and Sadaqah (ZIS) through the Zakat Institution.

The financial report, which is the end point of a series of accounting processes, is one of the determinants of Zakah Institution's reputation in muzaki's view. Thus, quality financial reports are an inevitable demand for public entities such as Zakah Institutions. The more quality the financial reports are presented, the more public interest will be in carrying out ZIS through Zakah Institutions. This is in accordance with what was concluded by [20] that the quality of accounting information has a significant effect on the level of receipt of zakat funds.

A quality financial report is a financial report that meets the characteristics that make the financial report as fully usable as possible by its users. These characteristics are based on the Basic Framework for the Preparation and Presentation of Sharia Financial Statements [9] which consists of being understandable, relevant, reliable and comparable. In addition, Zakah Institutions as a zakat entity, in preparing its financial statements refers to PSAK No. 109 which is a special standard regarding the preparation of Zakah Institutions financial statements. According to [32], one of the characteristics of a quality 
financial report is that it is in accordance with the accounting standards used.

Regarding the quality of financial reports in East Kalimantan Province based on previous research, it is still not satisfactory. However, many Zakah Institutions have slowly but surely adopted PSAK No. 109 in the process of preparing financial statements. [25] who conducted research related to exploration of amil's understanding of PSAK No. 109 concluded that in terms of understanding, the majority of amil already had a good understanding of PSAK No. 109. However, this understanding is not implemented as a reference for amil's work.

Based on research by [28] and [25], in terms of recognition, measurement, presentation and disclosure which are indicators of the application of PSAK No. 109, Zakah Institutions in East Kalimantan Province has not fully implemented it. Likewise with the financial statements presented, not all Zakat Institutions have presented the financial reports recommended by PSAK No. 109 which consists of a Balance Sheet, a Change in Funds Report, a Change in Asset Management Report, a Cash Flow Statement and Notes on Financial Statements. Based on previous research conducted by [17], [1] and [4] concluded that the application of PSAK No. 109 has a positive and significant effect on the quality of financial reports.

The quality of financial reports prepared and presented by Zakah Institutions depends on competent human resources in accounting. Financial reports as the final result of the accounting process require human resources who understand the ins and outs of accounting, especially zakat accounting. Competent human resources are the key to building and maintaining muzaki trust based on the financial reports that HR compiles and presents. Based on previous research conducted by [26] and [31] it can be concluded that HR competencies have a positive and significant effect on the quality of financial statements. Meanwhile, a different conclusion was expressed by [17] who concluded that human resource competence partially had no significant effect on the quality of financial statements.

Quality financial reports are also influenced by the use of Information Technology (IT). IT has a role in helping Zakat Institution financial managers in compiling and presenting quality financial reports. This is when compared with manual techniques, the use of IT in managing financial reports will certainly shorten the time, especially if there are data input errors. In addition, by utilizing IT in managing financial statements, it will reduce the risk of material miscalculations. Based on previous research stated by [22] the use of IT affects the quality of financial reports. However, contradictory results are stated by [1] and [26] where they reveal that the use of IT has no effect on the quality of financial statements.
Quality financial reports are financial reports that are free from fraud, in this case Internal Control (PI) has an important role. With the potential and the acquisition of ZIS funds that are quite large, to prevent fraud and fraud, it is necessary to implement a good PI. With a good PI, it is expected that all Zakat Institutions operational activities, especially the financial division, can run well and be controlled. In addition, with PI, Zakat Institutions finances can be monitored properly. This is so that Zakat Institutions can present objective, correct and reliable financial reports. So, it can produce quality financial reports. Based on research conducted by [7] and [1] PI has an effect on the quality of financial reports. Meanwhile, according to [14] PI has no effect on the quality of financial reports.

Based on some of the previous explanations, it can be seen that there are differences in research conclusions between each of the factors, this raises a research gap. In previous studies that have been previously mentioned, it shows that between the factors of HR competence, IT utilization and internal control, there are differences in the conclusions of the research results. In contrast to PSAK No. 109 where the majority of researchers agree that the application of PSAK No 109 has an effect on the quality of financial reports.

Some of the arguments and phenomena that have been previously described, are the reasons why these things deserve to be investigated further under the title, "The Quality of Financial Statements and Performance of Zakat Institutions"

\section{LITERATURE REVIEW}

\section{Shariah Enterprise Theory (SET)}

[30] states SET presenting a concept of responsibility, namely vertically and horizontally. Vertically, it means that everything in this world essentially belongs to God. In this case, humans are given the task to manage all these things. The consequence of this task is that humans must be responsible to God. Not only to God, humans are also required to be responsible to other humans and their natural surroundings, this is called horizontal responsibility. Regarding with the quality of Zakat Institution's financial reports, SET emphasizes the awareness of divinity and the responsibility of financial managers and related parties to present quality financial reports on the basis of competent human resources, applying PSAK No. 109 and internal control.

\section{Task Technology Fit Theory}

Goodhe and Thompson in [21] state that TTFT is a theory that explains the influence of IT capabilities or capabilities in providing convenience when doing a job. The theory is assumed to be able to help the performance of Zakat Institution's financial managers in preparing financial reports. Zakat Institution which provides 
facilities in the form of computers that are fit for use and always in prime condition, special programs or applications for compiling financial reports in accordance with PSAK 109, and the availability of adequate internet networks are believed to be able to assist Zakat Institution's financial managers in carrying out their duties, namely compiling financial reports quality.

\section{Zakah Institution's Financial Statement Quality}

Quality of financial statement is very important to determine the content [24]. According to the Basic Framework for the Presentation of Sharia Financial Statements [9], "qualitative characteristics are characteristics that make the information in financial statements useful for users". There are four indicators that can be used to measure the quality of financial reports as stated in SAK Syariah [9], namely: understandability, relevant, reliability, and comparability

As a public entity that accommodates funds from the public, Zakat Institution has the responsibility to present quality financial statement ([19], [13], [2]). This can help users, both external and internal to the Zakat Institution, in making economic decisions [3]. A concrete example in terms of making economic decisions is from the external party of the Zakat Institution, namely muzaki. Quality financial reports are an important source of information for muzaki in considering decision making to which Zakat Institution the muzaki's funds are entrusted.

\section{Competence of Human Resources (HR)}

Human Resource competencies according to [15] that the ability of a person or individual in an organization (institution) or a system to carry out their functions or authority to achieve their goals effectively and efficiently. There are three indicators that can be used to measure HR competencies as described by [29], namely: responsibility, training, and experience. It is directly related to the financial reporting process, HR is required to have adequate competence. This is related to the effectiveness and efficiency of work. Human resources who have the required competencies will have a positive impact in the form of shortening processing time, reducing the risk of errors and so on.

\section{Implementation of PSAK No. 109}

As a sharia-based public entity, namely an entity that collects, manages and distributes ZIS funds, Zakat Institutions in preparing its financial statements refers to PSAK No. 109 concerning ZIS Accounting. The following are matters related to the application of PSAK No. 109 as mentioned in the following Islamic SAK book [9]: confession, measurement, presentation, and disclosure. Through PSAK No. 109 in the preparation of Zakat Institutions financial statements will provide many benefits including having clear benchmarks, uniformity between reporting periods and between other zakat entities.

\section{Utilization of Information Technology (IT)}

The more advanced technological developments will provide many benefits. According to Walkinson et al., in [13], [23], "The use of technology as a benefit expected by users of information systems in carrying out their duties".

Involving IT in the preparation of Zakat Institutions financial reports will make it easier for financial managers to prepare quality financial reports. This is when compared with manual techniques, the use of IT in managing financial reports will certainly shorten the time, especially if there are data input errors. In addition, by utilizing IT in managing financial statements, it will reduce the risk of material miscalculations.

\section{Internal Control (PI)}

The definition of control according to [8] is a set of policies and procedures to protect company assets or assets from all forms of misuse, ensure the availability of accurate corporate accounting information, and ensure that all legal / statutory provisions (regulations) and management policies have been complied with or implemented properly by all company employees.

Zakat Institution as a public institution that accommodates many assets, both cash and non-cash originating from the community, is of course required to implement internal control. This is so that assets that have been entrusted by the community can be guaranteed their existence. The components of internal control according to the Indonesian Accounting Association in [6] consist of Control Environment, Risk Assessment, Control Activities, Information and Communication, and Monitoring. Thus, internal control system is expected that all operations, physical resources, and data will be monitored and controlled, organizational goals will be achieved, risks are reduced and the resulting accounting information will also be of higher quality and auditable.

\section{RESEARCH METHODOLOGHY}

The population in this study were Zakat Institution' financial managers in East Kalimantan Province. The Zakat Institution which was the location where this research took place consists of 12 Zakat Institutions consisting of BAZ and LAZ which were spread across several districts and cities in the province of East Kalimantan. The sampling method used in this study was the saturated sample method. The sample was 12 Zakat institutions in East Kalimantan with 57 respondents as financial managers. It is quantitative research, because the data obtained later is in the form of numbers extracted from the results of questionnaires and also uses literature from textbooks, articles, scientific journals, theses and the internet. The data collection method in this research 
was by using a questionnaire. The questionnaire was distributed by visiting the object of research in person, via post and electronic mail. Data analysis in this study used Partial Least Square - Structural Equation Modeling Analysis.

\section{RESULT AND DISCUSSIONS}

\section{Result}

Table 1. Output Variabel Coefficients

Figure 1. Research Model Output

\begin{tabular}{|l|l|l|l|l|l|}
\hline & KLK & SDM & SAK & TI & PI \\
\hline $\begin{array}{l}\text { Composite } \\
\text { Reliability }\end{array}$ & 0.953 & 0.881 & 0.967 & 0.923 & 0.939 \\
\hline $\begin{array}{l}\text { Cronbach's } \\
\text { Alpha }\end{array}$ & 0.946 & 0.840 & 0.962 & 0.894 & 0.927 \\
\hline AVE & 0.583 & 0.523 & 0.522 & 0.676 & 0.540 \\
\hline R-Squared & 0.855 & & & & \\
\hline Q-Squared & 0.855 & & & & \\
\hline
\end{tabular}

Based on the data on the output table of coefficients variables, the $\mathrm{R}$-squared value indicates how much the endogenous variable is affected by the exogenous variable. The R-squared of 0.855 explains that the variance in the financial statement quality of the Zakat Management Organization in East Kalimantan Province can be explained by the HR competency variable, the application of PSAK No. 109, IT utilization and Internal Control amounted to $85.5 \%$.

The value of Q-squared can be negative and positive, if the value of $\mathrm{Q}$ squared is greater than 0 then the research model has a good predictive value. Based on the results of data processing, the Q-squared value is $0.855>$ 0 , which indicates that the research model has good predictive validity.

The value of composite reliability and Cronbach's alpha as an indicator for measuring the reliability of the research instrument must be above 0.70 . Based on the output table of the coefficients variable, it can be seen that the value of composite reliability and Cronbach's alpha for the Financial Report Quality variable is $0.953>$ 0.70 and $0.946>0.70$, HR variables $0.881>0.70$ and $0.840>0.70$, SAK variable $0.967>0,70$ and $0.962>$ 0.70 , TI variable $0.923>0.70$ and $0.894>0.70$, PI variable $0.939>0.70$ and 0.927 .0 .70 . The composite reliability and Cronbach's alpha value of each variable in the study had a value above 0.70 , so it can be said that the measurement instrument for all variables met the reliability testing criteria. The AVE (Average Variance
Extracted) value for each variable is greater than 0.50 so that the research instrument is said to be valid

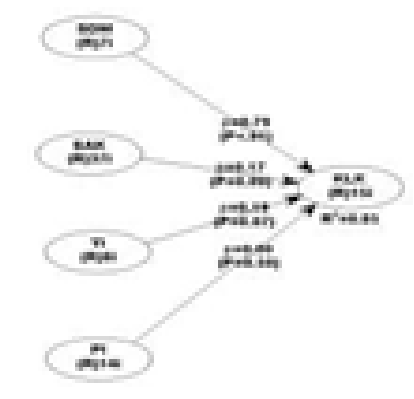

Figure 1. Research Model Output

\section{Discussions}

\section{The Effect of HR Competence on the Quality of Zakat Institution Financial Statements}

HR competence is the ability of individuals to carry out their duties, so that the stated goals can be achieved effectively and efficiently. Based on the results of data processing, HR competency as measured by three indicators, namely responsibility, training and experience, shows a significant relationship with a positive direction on the quality of Zakat Institution financial reports in East Kalimantan Province. The path coefficient value shows that HR competency has a positive effect of 0.793 and is significant with a p-value of $<0.001(<0.001<0.05)$, so it can be concluded that the first hypothesis is accepted. The results of data mean that the better the competencies possessed by human resources who work at Zakat Institution, the better the quality of the financial statements presented.

According to SET, the Zakat Institutions' financial manager has made God the center of everything and realizes that he is a mandate holder who has the consequences of being responsible and obeying His laws. This compliance is manifested in the form of working fully with the responsibility and this responsibility is manifested in the form of working on the basis of adequate competence. Working on the basis of these competencies is the responsibility of humans, with the output in the form of quality financial reports.

The results of this study are in accordance with what has been described by [26] and [31] which concluded that HR competence has a positive and significant effect on the quality of financial statements. However, the results of this study contradict what was concluded by [17] which stated that HR competency had no effect on the quality of financial statements. 


\section{The Effect of the Implementation of PSAK No. 109 Against the Quality of Zakat Institution Financial Statements}

PSAK No. 109 is a standard statement that aims to regulate the recognition, measurement, presentation, and disclosure of ZIS transactions. Based on the results of data processing, the application of PSAK No. 109 as measured by four indicators, namely recognition, measurement, presentation, and disclosure, shows an insignificant relationship with a positive direction towards the quality of Zakat Institution financial statements in East Kalimantan Province. The path coefficient value indicates that the application of PSAK No. 109 has a positive effect of 0.169 and it is not significant with a p-value of $0.090(0.090>0.05)$, so it can be concluded that the second hypothesis is rejected. The results of data processing mean the better the implementation of PSAK No. 109 in the Zakat Institution, the more quality the financial reports are presented. However, because it is not significant, the implementation of PSAK No. 109 does not have a major effect on the quality of Zakat Institution financial reports in East Kalimantan Province.

There are not all Zakat Institutions presenting the financial report format recommended by PSAK No. 109. This is due to several factors. First, some Zakat Institutions are registered as branch offices, so as stated by [10] and

[16] that the financial reporting system is centralized or in other words, the branch office Zakat Institution only presents reports on sources and uses of funds while the format of financial reports others are arranged centrally. Second, with regard to policy, as stated by [25] the majority of Zakat Institution financial managers have a fairly good understanding of PSAK No. 109, however, this understanding was not implemented in the process of preparing the financial statements because financial managers felt that PSAK No. 109 are more complicated than the policies they have implemented so far. Third, some Zakat Institutions only present performance reports based on SiMBA, which is a data entry system initiated by BAZNAS which also refers to PSAK No. 109.

According to SET, the Zakat Institution financial manager has made God the center of everything and realizes that he is the holder of the mandate and awareness of God which has consequences for obeying and obeying His laws. This compliance is manifested in the form of preparing financial statements in accordance with generally accepted standards. As a trustee, financial managers who have divine awareness always try their best to prepare quality financial reports in accordance with standards. This is a form of responsibility to God and humans who are indirectly affected by decisions made by humans based on these financial statements.
The results of this study contradict what was stated by [17], [1], and [4] that the application of PSAK No. 109 has a significant effect on the quality of Zakat Institution's financial statements.

\section{The Effect of IT Utilization on the Quality of Zakat Institutions Financial Statements}

Utilization of IT is the benefit expected by users when doing their tasks. The IT utilization variable is measured by two indicators, namely the use of computers and Internet networks. Based on the results of data processing, it can be concluded that the IT utilization variable has a positive and insignificant effect on the quality of Zakat Institutions financial reports in East Kalimantan. This can be seen from the positive path coefficients of 0.189 with a significance value of 0.066 $(0.066>0.05)$. The meaning of the data processing is the better the use of IT in preparing financial reports, the better the quality of the financial reports will be. However, because it was not significant, the use of IT did not have a major effect on the quality of Zakat Institurions's financial reports.

The use of IT has no significant effect on the quality of financial reports is not appropriate with the Task Technology Fit Theory (TTFT), where the expected benefits of using IT in facilitating a job are good but not maximized, so that it affects the quality of the report. Financial statements are presented by the Zakat Institutions, particularly in terms of timeliness in presenting financial reports.

The results of this study are appropriate with what was expressed by [27] which stated that the use of IT had a positive and insignificant effect on the quality of financial reports. Meanwhile, different conclusions were expressed by [22] and [33] which stated that the use of IT had a positive and significant effect on the quality of financial statements.

\section{The Effect of Internal Control on the Quality of Zakat Institution Financial Statements}

Internal control (PI) is a policy or procedure designed to provide adequate assurance to management that Zakat Institution has achieved its goals and objectives. PI variable is measured by five indicators, namely control environment, risk assessment, control activities, information and communication and monitoring. Based on data processing, it can be seen that internal control variables have a positive and insignificant effect on the quality of financial statements. This can be seen from the positive value of the path coefficients of 0.002 with a significance value of $0.499(0.499>0.05)$. The meaning of the data processing is the better the PI is implemented, the better the quality of the financial statements that are presented. However, because it is not significant, the use of PI does not have a major effect on the quality of Zakat Institution's financial reports. 
According to SET, the Zakat Institution financial manager has made God the center of everything and realizes that he is a mandate holder, which has the consequences of obeying and obeying His laws and also being responsible to fellow humans and nature. In this case, Zakat Institution has implemented PI in financial management activities. Although, several indicators still need to be maximized but this does not eliminate the manifestation of Zakat Institution's main responsibility to God, namely applying PI to control Zakat Institution finances to produce quality Zakat Institution financial reports.

The results of this study are appropriate with what was expressed by [11] which states that PI has no significant effect on the quality of financial statements. This conclusion is different from what was concluded by [7], [18] and [1] which stated that PI has a significant effect on the quality of financial statements.

\section{CONCLUSIONS AND SUGGESTIONS}

Based on the discussion of the results, human resource competence has a positive and significant effect on the quality of Zakat Institutions financial reports in East Kalimantan Province. It can be said that the more competent the human resources are in managing Zakat Institutions finances, the better the quality of the financial reports that are presented. Moreover, implementation of PSAK No. 109 have a positive and insignificant effect on the quality of Zakat Institutions financial statements in East Kalimantan Province. Thus, the application of PSAK No. 109 only has a small contribution to the quality of Zakat Institutions financial reports in the province of East Kalimantan. IT utilization has a positive and insignificant effect on the quality of Zakat Institution financial reports in East Kalimantan Province. This means that the use of IT only has a small contribution to the quality of Zakat Institution financial reports in East Kalimantan Province. Indeed, internal control has a positive and insignificant effect on the quality of Zakat Institution financial reports in East Kalimantan Province. It is recommended that zakat institutions must increase their capacity in PSAK 109 and to maximize the use of IT, especially in terms of financial management. Indeed, the Zakat Institution needs to regularly monitor financial records on a regular basis, so as to provide assurance and confidence that the financial records are presented in an honest and true manner.

\section{ACKNOWLEDGMENTS}

We would like to thank Zakat Institution especially BAZ and LAZ are located in several districts and cities in the province of East Kalimantan for supporting us in giving the research data.

\section{REFERENCES}

[1] Apriliani, E., \& Jayanto, P. Y. (2017). Analysis of Determinant of Financial Statements Quality of Amil Zakat Agencies in Semarang City. Accounting Analysis Journal, 6(2), 264-276. https://doi.org/10.15294/aaj.v6i2.15409

[2] Al-Dmour, A., Abbod, M., \& Al-Balqa, N. (2018). The impact of the quality of financial reporting on non-financial business performance and the role of organizations demographic'attributes (type, size and experience).

[3] Cohen, D. A. (2003). Quality of financial reporting choice: Determinants and economic consequences. Available at SSRN 422581.

[4] Darisah, S. R., Sofianty, D., \& Sukarmanto, E. (2018). Pengaruh Kompetensi Sumber Daya Manusia dan Penerapan PSAK No 109 tentang Akuntansi Zakat, Infaq dan Sedekah terhadap Kualitas Laporan Keuangan (Studi Kasus pada Lambaga Amil Zakat di Kota Bandung). Prosiding Akuntansi, 4(1), 451-457.

[5] Ghozi, Fahrul. (2018). Wawancara oleh Siti Khairiyah. RRI, 30 Mei. Diakses pada 6 Juni 2019. http://www.rri.co.id/samarinda/post/berita/533772/ sosial_dan_budaya/baznas_kaltim_datangkan_paka r_zakat_dari_sudan_dan_malaysia_untuk_optimal_ zakat.html

[6] Hamidi, N., \& Suwardi, E. (2013). Analisis Akuntabilitas Publik Organisasi Pengelola Zakat Berdasarkan Aspek Pengendalian Intern Dan Budaya Organisasi (Survei pada Organisasi Pengelola Zakat di Indonesia). Ekonomi Dan Bisnis Islam, VIII(1), 1-22.

[7] Herawati, T. (2014). Pengaruh Sistem Pengendalian Intern Terhadap Kualitas Laporan Keuangan. STAR - Study \& Accounting Research, XI(1), 1-14. https://doi.org/10.32897/sikap.v2i1.64

[8] Hery. (2015). Pengantar Akuntansi. Jakarta: Gramedia.

[9] Ikatan Akuntan Indonesia (IAI). 2017. Standar Akuntansi Keuangan Syariah. Jakarta: Ikatan Akuntan Indonesia (IAI).

[10] Kristin, Ari, Umah, Umi Khoirul. (2011). Penerapan Akuntansi Zakat Pada Lembaga Amil Zakat (Studi Kasus Pada LAZ DPU DT Cabang Semarang). VALUE ADDED, 7, (2), 68-97.

[11] Latifah, A. (2017). Pengaruh Penerapan Standar Akuntansi Pemerintah, Sistem Akuntasi Keuangan Daerah, Kompetensi Sumber Daya Manusia dan Sistem Pengendalian Internal Terhadap Kualitas 
Informasi Laporan Keuangan Daerah (Studi Kasus pada SKPD Bantul). Universitas PGRI Yogyakarta.

[12] Mahboub, R. (2017). Main determinants of financial reporting quality in the Lebanese banking sector.

[13] Mardinan, T., Dahlan, M., \& Fitriyah, F. K. (2018). Effect of Human Resources, Leadership Style, The Use of Information Technology and Internal Control on the Quality of Financial Statements. Journal of Accounting Auditing and Business, 1(1), 43-57.

[14] Mokoginta, N., Lambey, L., \& Pontoh, W. (2017). Pengaruh Sistem Pengendalian Intern dan Prinsip Pengelolaan Keuangan Daerah terhadap Kualitas Laporan Keuangan pada Pemerintah Daerah Kabupaten Bolaang Mongondow Selatan. Jurnal Riset Akuntansi Going Concern, 12(2), 874-890.

[15] Muda, I., Wardani, D. Y., Maksum, A., Lubis, A. F., Bukit, R., \& Abubakar, E. (2017). The Influence of Human Resource Competency and The Use of Information Technologhy on The Quality of Local Government Financial Report with Regional Accounting System as an Intervening. Journal of Theoretical \& Applied Information Technology, 95(20).

[16] Mujahidi, Khairul. (2016). "Analisis Penerapan PSAK 109 Dalam Penyusunan Laporan Keuangan Pada Lembaga Amil Zakat (Studi Kasus Pada Baitul Maal Hidayatullah Cabang Malang)”. Fakultas Ekonomi, Universitas Islam Negeri Maulana Malik Ibrahim.

[17] Nasrullah, N. (2014). Pengaruh Kompetensi Sumber Daya Manusia Dan Penerapan Standar Akuntansi Zakat, Infak dan Sedekah (PSAK NO 109) Terhadap Kualitas Laporan Keuangan, 1-31. https://doi.org/10.1017/CBO9781107415324.004

[18] Naz'aina. (2015). The Effect of Internal Control System and Amil Competence on the Financial Reporting Quality at Zakat Management Institution Active Member of Zakat Forum in Special Capital City Region Jakarta and West Java Provinces. Procedia - Social and Behavioral Sciences, 211, 753-760. Retrieved from http://www.sciencedirect.com/science/article/pii/S1 877042815054403

[19] Nirwana, N., \& Haliah, H. (2018). Determinant factor of the quality of financial statements and performance of the government by adding contextual factors. Asian Journal of Accounting Research.

[20] Nurhayati, N., Fadilah, S., Iss, A., \& Oktaroza, M. L. (2014). Pengaruh Kualitas Informasi Akuntansi, Akuntabilitas dan Transparansi Pelaporan
Keuangan Terhadap Tingkat Penerimaan Dana Zakat pada Badan Amil Zakat (BAZ) di Jawa Barat. Prosiding SNaPP2014 Sosial, Ekonomi, Dan Humaniora, 4(1), 577-584.

[21] Permana, I. B. G. A., \& Setianto, D. P. (2017). Pengaruh Task Technology Fit, System Quality dan Information Quality terhadap User Performance: Perceived Usefulness dan Perceived Ease Of Use Sebagai Pemediasi. Jurnal Manajemen Teori Dan Terapan | Journal of Theory and Applied Management, 10(3), 231-242. https://doi.org/10.20473/jmtt.v10i3.7058

[22] Rahman, D. (2015). Pengaruh Pemanfaatan Teknologi Informasi, Penerapan Sistem Akuntansi Keuangan Daerah, dan Penerapan Standar Akuntansi Pemerintahan terhadap Kualitas Laporan Keuangan Daerah (Studi Empiris pada Skpd Provinsi Riau). Jurnal Online Mahasiswa Fakultas Ekonomi Universitas Riau, 2(2), 1-15.

[23] Rahmawati, D. (2008). Analisis Faktor Faktor yang Berpengaruh Terhadap Pemanfaatan Teknologi Informasi. Jurnal Ekonomi Dan Pendidikan, 5(1), 107-118. https://doi.org/10.21831/jep.v5i1.606

[24] Renkas, J., Goncharenko, O., \& Lukianets, O. (2015). Quality of financial reporting: approaches to measuring. International Journal of Accounting and Economics Studies, 4(1), 1-5.

[25] Setiawan, A., Yuningsih, I., \& Sari, D. M. (2016). Eksplorasi Pemahaman Badan Amil Zakat Nasional (BAZNAS) Terhadap PSAK NO 109 (Studi Pada BAZNAS Provinsi Kalimantan Timur). Simposium Nasional Akuntansi XIX, Lampung. https://doi.org/10.1109/ICUAS.2013.6564698

[26] Setyowati, L., Isthika, W., \& Pratiwi, R. D. (2016). Faktor-Faktor yang Mempengaruhi Kualitas Laporan Keuangan Pemerintah Daerah Kota Semarang. KINERJA, 20 (2), 179-191.

[27] Surastiani, D. P., \& Handayani, B. D. (2015). Analisis Faktor-faktor yang Mempengaruhi Kualitas Informasi Laporan Keuangan Pemerintah Daerah. Jurnal Dinamika Akuntansi, 7(2), 139-149. Retrieved from http://journal.unnes.ac.id/nju/index.php/jda

[28] Susanti, Hasanah, Irwansyah, \& Musviyanti. (2015). Pengeluaran Pemeliharaan Aset Tetap PT. Pupuk Kalimantan Timur Divisi Jasa Pelayanan Pabrik di Kota Bontang, Akuntabel, 12, (2), 132155.

[29] Triyanto, H. (2017). Pengaruh Kompetensi Sumber Daya Manusia, Pengendalian Internal, Pemanfaatan Teknologi Informasi Dan Peran Inspektorat Daerah 
Terhadap Kualitas Laporan Keuangan Daerah (Studi Empiris Pada Satuan Kerja Perangkat Daerah Kabupaten Kulon Progo). Fakultas Ekonomi dan Bisnis Universitas Muhammaidyah Yogyakarta.https://doi.org/10.1017/CBO97811074 15324.004

[30] Triyuwono, Iwan. (2015). Akuntansi Syariah Perspektif, Metodologi, dan Teori. Jakarta: Rajawali Pers.

[31] Wati, K. D., Herawati, N. T., \& Sinarwati, N. K. (2014). Pengaruh Kompetensi Sdm, Penerapan SAP, Dan Sistem Akuntansi Keuangan Daerah Terhadap Kualitas Laporan Keuangan Daerah. EJournal S1 Ak Universitas Pendidikan Ganesha, 2(1).

[32] Yadiati, Winwin, Mubarok, Abdullah. (2017). Kualitas Pelaporan Keuangan (Kajian Teoritis dan Empiris). Jakarta: Kencana.

[33] Yuniatin, N. Y., Achsani, N. A., \& Sasongko, H. (2018). Pengaruh Perubahan Status, Employee Engagement, dan Pemanfaatan Teknologi Informasi Terhadap Kualitas Pelaporan Keuangan. EKUITAS (Jurnal Ekonomi dan Keuangan), 19(4), 495-515. 